\title{
“O CIDADÃO NÃO ENCONTRA GARANTIA SENÃO NA PRÓPRIA FORÇA" - Recrutamento, milicias privadas, quadrilhas de 'cabras' e a propriedade privada(Cariri Cearense, século XIX)
}

\author{
Ana Sara Cortez Irffi*
}

RESUMO: Este artigo se propõea analisar,no processo de construção do Estado brasileiro em meados do Oitocentos, o recrutamento para a Guarda Nacional e a formação de milícias privadas no sertão nacional, sobretudo das chamadas províncias do Norte. A análise se volta às milícias surgidas a partir das relações estabelecidas dos senhores com agregados e moradores, mas também, no bojo desse processo, à formação de grupos alheios aos senhores que ficaram conhecidos como 'quadrilhas de cabras'.

PALAVRAS-CHAVE: Estado Brasileiro; Recrutamento; Século XIX.

\section{"The citizen has no guarantee but only in their own strength" - Recruitment, private Militias, gangs of 'cabras' and the private property (Cariri Cearense, $19^{\text {th }}$ century)}

ABSTRACT: This article aims to analyze in the Brazilian state-building process in the mid- nineteenth century, the recruitment for the National Guard and the formation of private militias in the national hinterland, especially in the so-called north provinces. The analysis turns to the militias that emerged from the established relationships between the lords households and residents, but also, in the midst of this process, the formation of groups unrelated to the lords, that became known as 'gang of cabras'.

KEYWORDS: Brazilian state; Recruitment; 19th Century.

\section{"EI ciudadano sólo tiene garantías en sus propias fuerzas" - Reclutamiento, milicias privadas, pandillas de 'cabras' y la propiedad privada (Cariri Cearense, siglo XIX)}

RESUMEN: Este artículo tiene como objetivo analizar el proceso de construcción del Estado en Brasil a mediados del siglo XIX, el reclutamiento para la Guardia Nacional y la formación de milicias privadas en el interior del país, especialmente en las denominadas provincias del norte. El análisis dedica atención a las milicias que surgieron de las relaciones establecidas entre los señores y los agregados y habitantes, y también, en el marco de este proceso, a la formación de grupos no relacionados a los señores que se conocían como "banda de cabras".

Palabras clave: Estado de Brasil; Contratación; siglo XIX.

\footnotetext{
*Doutora em História Social pela Universidade Federal do Ceará. Professora de História Econômica na Universidade Federal do Ceará - Campus de Sobral. Email:anasaracortez@ gmail.com.
} 
Os anos que sucederam a revolta do Pinto Madeira, ocorrida entre 1831 e 1832 no Ceará, e o período regencial foram marcados por transformações e intensos debates políticos no Brasil a fim de evitar novas insurreições, mas também acerca da conformação da população ao modelo de governo do chamado Regresso. Naquele momento, havia duas prioridades: a manutenção da escravidão, e, se possível, também do tráfico, e a estruturação da população livre e pobre à participação nas forças armadas e, sobretudo nas chamadas 'Províncias do Norte', ao trabalho conjunto com os escravizados. Entretanto, os interesses dos senhores e das populações locais nem sempre se coadunavam com a corte imperial e, por essa razão, a tentativa de organização das elites e populações pobres se mostrou conturbada. De outra parte, é preciso entender que senhores e trabalhadores tinham posições políticas distintas, embora, em determinados momentos, grupos das camadas mais baixas tenham se aliado a proprietários locais, como na tentativa de burlar o recrutamento.

O objetivo do presente artigo é analisar o processo de construção de milícias privadas no sertão nacional, e mais especificamente no Cariri Cearense, surgidas a partir das relações estabelecidas com agregados e moradores, bem como a contrapartida dessas relações, a formação de grupos alheios aos senhores. Também é interesse perceber as interpretações ressaltadas acerca do recrutamento imposto pelo governo Imperial e da, em contrapartida, recusa em participar desse processo tanto dos senhores como dos grupos que não se submetiam às ordens de um senhor, nem como seus trabalhadores ou seus milicianos.

Em meados do Oitocentos, no Cariri Cearense, a elite social apontava que a maior urgência se faziana disponibilidade de mão-de-obra e de um exército disponível para a proteção dos senhores mais abastados da região, preferencialmente alheios à Guarda Nacional e voltados aos interesses privados de cada senhor. Diante da necessidade de ter homens sujeitos a si, os senhores passaram a recrutar moradores e agregados. Nesse momento, o governo provincial, de seu lado, também o fazia em prol de sua própria militarização.

Essa militarização, tanto privada quanto pública, aconteceu a custo do processo de expropriação do homem à terra, sobretudo com a Lei de Terras, de 1850. Os homens que viviam em áreas férteis, no espaço rural, com suas famílias e trabalhavam por sua sobrevivência foram impelidos a se aliarem aos senhores mais abastados a fim de terem acesso a terra. Aliado ao receio das constantes contagens populacionais terem o efeito de uma escravização, ou mesmo de uma reescravização, muitos campesinos passaram a se sujeitar a um senhorem troca de proteção à intervenção governamental e de moradia, em troca do trabalho prestado ao dono da propriedade. 
A relação de sujeição aos senhores, contudo, apresentou outros desdobramentos: o senhor utilizava seus homens também para a sua proteção pessoal e a da sua propriedade. Foram, nesse sentido, instituídos serviços de 'capangas' aos cabras. Eram os homens do 'coronel'. ${ }^{1}$ Ao que parece, esse tipo de atitude foi tolerada pela sociedade, que apenas percebia uma incongruência em tal costume quando se tratava de um senhor rival, que participasse do partido político opositor.

Por outro lado, esses homens, chamados cabras, se não estivessem sob a sujeição/proteção de um senhor, eram entendidos como homens perigosos e criminosos em potencial. Ao contrário de quando estavam a serviço de seus senhores e disputavam as suas querelas, ocasião em que eram entendidos como homens de proteção dos seus senhores. Em todo caso,quando não se sujeitavam a um senhor e suas questões - sobretudo - políticas, eram chamados de cabras, ficando, ainda, a percepção de uma quadrilha, o que reforçava uma identificação negativa sobre esses homens.

\title{
O Recrutamento e a (des)organização das milícias no sertão do Cariri
}

\begin{abstract}
Consta-nos que esta detido na cadeia publica à ordem do senhor delegado de polícia, Paulo Manoel dos Santos que se diz escravo. Preso por andar armado de faca e cacete em um grupo de 8 pessôas, esta sofrendo o rigor da prisão por ter confessado andar fugido. Achamos injustiça o deter-se hum homem sem crime. E a policia deixe este papel que é muito feio. Não queremos quilombos, mas não queremos também que a policia dessa [desça] a .......... capitão de campo (sic). ${ }^{2}$
\end{abstract}

A denúncia feita pelo redator do jornal Vanguarda, periódico de natureza liberal, editado no Crato nos anos de 1887 e 1888, em seu terceiro número, trouxe arraigada em si tensões pelas quais passava não apenas a sociedade do Cariri Cearense, mas a nação brasileira, acerca da manutenção da ordem pública e, por outro lado, das preocupações em torno da vigilância sobre a população. $\mathrm{O}$ meio termo procurado - entre o quilombo e o capitão de campo - ilustrava a persistência de dois medos: o aparecimento de grupos de criminosos e a impossibilidade de se transitar pela cidade.

A questão, entretanto, não se voltava à defesa do suposto escravo, mas na possibilidade da polícia passar a controlar a população. O que se pretendia, na verdade, era a segurança garantida pela polícia, mas essa interferência somente iria até o limite de que a liberdade de controlar as suas posses, propriedades e, mesmo, direcionar a própria vida, fosse preservada. A polícia, nesse sentido, deveria agir até ao ponto de garantir a vida e, sobretudo, 
a propriedade privada da elite senhorial. Deveria prender os 'bandidos' e, de outra parte, deixar a população ‘de bem’ em segurança.

Por outro lado, a atitude do homem detido, em se dizer escravo, numa época em que já havia sido abolida a escravidão no Ceará - desde $1884^{3}$, é intrigante. Seu nome, acompanhado de sobrenome, indicava ser uma pessoa livre. Ainda assim, Paulo Manoel dos Santos insistiu em se dizer cativo. Atitude, provavelmente, tomada a fim de fugir a um destino bastante comum a pessoas consideradas desordeiras e sem ocupação, sobretudo na segunda metade do século XIX: o recrutamento. Esse ato, no mais das vezes, significava a inscrição forçada de homens para o serviço militar, fosse na polícia ou na chamada Guarda Nacional. Conforme Marcelo Baladan, o recrutamento foi instituído pela Instrução de 10 de julho de 1822 , sofrendo modificações até 1874.Em teoria, o recrutamento atingia, inicialmente, homens brancos e pardos solteiros, que tinham entre 18 e 35 anos de idade e que não tivessem nenhuma isenção legal. ${ }^{4}$

As regras que definiam as isenções, válidas para a formação dos "Corpos da 1". linha", estavam voltadas àqueles que "bem servissem à pátria”, fosse por terem profissão considerada honesta, ou por ser considerado útil a sua família. Em suma, estariam isentos do recrutamento aqueles empregados em "honesta, e legal indústria", "fontes da prosperidade pública". $\mathrm{Na}$ prática, indivíduos que não estivessem enquadrados em nenhuma dessas prerrogativas estavam necessariamente à mercê do processo de recrutamento. Jonny Araújo, em tese sobre o recrutamento militar no Piauí, apontou que "em nível provincial, as turmas de recrutamento representavam o verdadeiro terror para grande parte da população livre e excluída que vivia à margem do processo produtivo". Fazendo com que muitos se dirigissem para esconderijos no interior da Província. ${ }^{6}$ Dessa maneira, ao serem apanhadas em situações duvidosas, as pessoas eram inquiridas e deveriam provar se estavam na dependência de um senhor ou se eram cativos, como o fez Paulo Manoel dos Santos.

Entretanto, afirmar-se cativo podia trazer desdobramentos perigosos, uma vez que o suposto escravo, no caso do não aparecimento de um senhor que atestasse sua posse, podia ser obrigado a serviços pesados ou ser vendido no tráfico interprovincial. Talvez pelo receio de ser realmente escravizado ou vendido para o sul cafeicultor, essa não tenha sido a estratégia corriqueira dos homens em perigo de recrutamento, no Cariri Cearense. A maior probabilidade era que ocorressem embates entre a população, a fim de se livrar de um alistamento forçado, e os inspetores de quarteirão e/ou a polícia. 
Em 1881, ocorreu um caso que aponta para a querela permanente entre as duas partes. Raimundo Valleu, Manoel dos Reis, Henrique de Tal, João Canela Fina, Raimundo Cajarana e Benedicto Cheirôzo foram acusados de atacarem um soldado de polícia no momento em que fazia a ronda juntamente com seus companheiros de profissão, como atestou a própria vítima.

Respondeo que andando de ronda elle respondente nesta cidade com mais três soldados e o carcereiro Manoel Francisco, ao chegarem na esquina de Antonio Alves d'Oliveira Martins, na rua da valla, incontrarão-se com huns des a dose cabras desconhecidos e armados de cacete e faca, e dirigindo-se estes para elles da ronda, irromperão nestas palavras: morrãos os soldados, e dando-se a lucta entre ambos, um dos cabras aproveitando a omissão em que elle respondente luctava com hum outro deu-lhe de banda e a traição a furada de que esta soffrendo abaixo do umbigo a qual so veio elle respondente a sentir quando ditos cabras (ilegível) e pararão a lucta e derão ordem a correr ficando no poder deles rondantes um chapeo de couro e um cacête de ditos cabras, não podendo ser prêzo ou conhecido um so destes.

Se, de fato, havia no início do confronto dez a doze cabras, pelos menos quatro deles parecem ter se evadido com sucesso; sendo indiciados apenas seis. De toda maneira, a declaração feita por Manoel Joaquim Tajujá, soldado de polícia de Crato, acerca da facada que sofreu, e da qual viria a falecer no dia seguinte, de cabras que circulavam no espaço citadino, permite a percepção da construção destes homens como pessoas alheias às regras ditadas pela sociedade da época: foram considerados foras-da-lei, ou bandidos.

De outro ângulo, o relato do soldado deixou entrever a pretensa organização da sociedade e dos homens que serviam aos senhores. Manoel Joaquim anunciou que foi atacado por um grupo que considerou como cabras desconhecidos. Sua referência não apenas indicava que eram homens desconhecidos por ele, mas, principalmente, que esses indivíduos não eram socialmente distinguidos como sendo vinculados a nenhum senhor da região. Sendo assim, não tinham protetores.

Esse estranhamento se dava em virtude de serem comuns às referências aos protetores dos homens livres pobres da região caririense. Em 09 de janeiro de 1858, n'O Araripe havia a seguinte nota: "Francisco José de Sousa é criminoso, por achar-se pronunciado pela Subdelegacia de Santa-Ana do Brejo-grande, no entanto, vive em santa paz no destricto do Crato, sem temer a justiça porque tem protector. Luis Alves de O".7

Por outro lado, é possível inferir que os cabras reagiram, com o grito de morrão os soldados, por entenderem a gravidade de sua situação. A explicação para o fato de reagirem de forma imediata e, segundo consta, com tamanha agressividade estava na experiência adquirida por esses homens ao longo de uma vida e também passada por seus pais. Tais 
cabras reagiram à autoridade policial pela possibilidade de serem detidos e não terem quem os 'protegessem' e os livrassem da prisão ou de serem recrutados.

Tamanho receio era explicado pelo fato do processo para recrutar pessoas seguir uma ordem essencialmente hierárquica. Ainda é Marcelo Balaban quem lembra ser este movido em função da "hierarquia social: quanto mais importante o indivíduo, melhor a situação social, menor a chance de ser recrutado. Tais regras definiam hierarquias e diferenças sociais. O equilíbrio social estava em grande medida centralizado no recrutamento" ${ }^{8}$ Os habitantes livres do país estavam nos diversos escalões da Guarda Nacional; os chefes locais que tivessem mais prestigio ocupavam postos mais elevados, os chamados 'coronéis'; depois, vinham capitães e outros chefes não tão importantes, tendo sob suas ordens os que não podiam ocupar melhores posições. Nesse sentido, a Guarda Nacional espelhava a estrutura socioeconômica das diversas regiões. "“A guarda nacional” era uma "instituição organizada para desenvolver diferentes modalidades de controle social, que definiam tanto sua atuação quanto sua estruturação interna". 10

Quanto ao processo de recrutamento, seria formada uma milícia - segundo José Almeida, "fundada como tropa auxiliar do exército" - a fim de controlar as insurreições que estavam ocorrendo em todo território brasileiro. Fundada como tropa auxiliar do exército, tinha como objetivo dar apoio às tropas de primeira linha na defesa da soberania do país e garantir a manutenção da ordem interna. Jeanne Castro apontou que a Guarda Nacional “sofreu, no processo de adaptação às condições brasileiras, 'interpretações' decorrentes da mentalidade familiar-patriarcal dominante.Naquela sociedade agrária, pensava-se em termos de privilégios pessoais e de classe e a obediência a preceitos legais em benefício do Estado tinha pouca significação". 11

Nesse sentido, a Guarda Nacional seria mais um meio para organizar o poder em torno da elite senhorial e, por fim, serviria de mais um espaço para a disputa de poder. Conforme Miriam Dolhnikoff, "a Guarda Nacional tornou-se um aparato eficiente na manutenção da ordem interna e foi a principal força coercitiva utilizada pelo governo central para a repressão das revoltas que abalariam a Regência". ${ }^{12} \mathrm{Nada}$ obstante, ainda era um meio para o controle dos braços que não estivessem dispostos ao trabalho.

No Cariri Cearense, a possibilidade do alistamento forçado terminava por assustar a todos, sendo mais aterradora para as populações pobres e desamparadas, dadas as lembranças do recrutamento ocorrido por ocasião da Guerra da Cisplatina, na década de 1820. Anos à frente, esse medo apenas aumentou. No ofício enviado em 18 de outubro de 1841 para a 
Presidência do Ceará, pelo Brigadeiro José Joaquim Coelho, pela Câmara de Vereadores da Comarca de Crato, foi argumentado que "no maior apuro de necessidade, hem huma terrível colizão entre o respeito devido as ordens de V. Exa e a forma que amiassa-nos". No documento, alegava ser o Cariri um "pais agricula, e de terreno curto", com uma população considerável pela falta de inverno, que fez dobrar o numero dos concorrentes. Sua reclamação se voltava ao que chamou de "indiscreto recrutamento do tenente Jacarandá", pelo abandono das lavouras, em face da obrigatoriedade do recrutamento. ${ }^{13}$

Entretanto, a resistência ao recrutamento não se restringia à população pobre e desocupada, na consideração dos vereadores do Crato, mas incomodava a possibilidade dos senhores ficarem sem mão-de-obra para o desenvolvimento de suas atividades econômicas. Assim, também argumentavam contra o recrutamento em face da insuficiente oferta de trabalhadores de que dispunha a região, mas também pelo medo de que os recalcitrantes formassem grupos alheios aos senhores no sertão comum às províncias do Norte. Apontaram que "as pessoas que estão no cazo de serem recrutadas, huns tem deixado o pais, e outros tem se embrenhado nos matos de onde serão difíceis saírem, com o que causão inormissima falta a Agricultura, por serem nesse pais o braço livre único que da impulço as produções de suas riquezas, visto que o numero de Escravos he sumamente deminuto". ${ }^{14}$

Da mesma maneira, na publicação do periódico $O$ Araripe em 21 de fevereiro de 1857, o Vigário Luis Antonio Marques da Silva Guimarães, sobre ditames da polícia reclamou sobre ditames da polícia e quanto aos prejuízos do recrutamento para os trabalhos de agricultura, em seus sítios, e seus moradores:

\footnotetext{
V. Exm. conhece muito bem quanto essa industria tem diminuído com a falta dos escravos, e que indispensavelmente se fasem precisos braços livres, principalmente a mim, que trabalho em quatro sitios differentes, em cada um dos quais ja tenho engenho de moer cannas, serviço este bastante pesado; e vivendo eu Exm. Sr. com meus moradores perseguidos da policia, que lucro tirarei e elles para manterem suas famílias e pagar de disimo $300 \$$ a $400 \$$ reis anuaes? ? $^{15}$
}

De acordo com a alegação, eram recrutados para o serviço na Guarda Nacional e no exército homens ligados aos senhores de posições políticas antagônicas. Da mesma maneira, sob as iniciais J. R., um senhor de Missão Velha criticou a forma de recrutamento feita naquela vila. Em sua opinião, "aquelles recrutados são bons rapazes, trabalhadores e de bons costumes; no entretanto que os vadios abundão por aqui”. ${ }^{16}$

O recrutamento desestruturava o espaço e a lógica da produção, na medida em que atingia a senhores, que perdiam em volume de mão-de-obra, e aos trabalhadores, que eram 
afastados de sua parentela. A reclamação não foi feita, todavia, por um senhor a fim de proteger seus moradores, obrigação a que este proprietário se devia em troca dos dias de trabalho de seus trabalhadores; mas na defesa de sua produção. O que, em última instância, apontava para o fato de que os moradores tinham suas vivências marcadas pelos interesses econômicos dos seus senhores e a sua proteção também estava relacionada a isso.

Entretanto, e muito embora existissem reclamações tanto oficiais, pelas autoridades governamentais, quanto dos jornais, pelos moradores da comarca de Crato, nada foi alterado. Pelo contrário, com o tempo, o recrutamento passou a se mostrar essencialmente uma questão política e uma forma de submeter aqueles que não estivessem sob a proteção do grupo que controlava em alguma medida o aparato governamental. Anos depois, em 1847, foram feitas novas denúncias acerca das ameaças de recrutamento por membros do partido opositor ao governo, naquele caso, pelos liberais. Conforme ofício da Câmara, obrigavam "sem motivo a assignação de termos de bem viver, amiassando recrutar a quem não prometesse votar em sua chapa". Salientava, ainda, que "hante hontem a tarde entrou para esta villa huma grande porção de povo armado mandado vir do Brejo Grande para a conquista eleitoral” e Vicente Amancio de Lima, Antonio Brígido dos Santos, o pároco Manoel Joaquim Aires do Nascimento, entre outros, "cercarão a Igreja" a fim de "não consentir que se fizesse a eleição, senão pela forma e maneira que a victoria lhe fosse dada". ${ }^{17}$

A defesa feita no ofício da Câmara, embora alicerçada nos cuidados para com a população pobre, evidenciava o impasse político que existia naquela região e que se desdobraria por toda a segunda metade do século XIX. Para o Cariri Cearense, o recrutamento foi tomado desde sempre como uma questão problemática e motivado por interesses políticos. Sob o título de "Horror! Vergonha!", o jornal O Araripe noticiou a prisão de José de Sousa Monteiro a quem chamou de "victima de ódios particulares". ${ }^{18}$ Em outra ocasião, publicou contra os saquaremas as denúncias de que estes, às vésperas da eleição faziam "amiaças de prisão e recrutamento, ostentação de poderio oficial, promessas de proteção, descomposturas, enfim tudo". ${ }^{19}$

De acordo com Wilma Peres, a organização das forças armadas profissionais era parte do projeto de construção do Estado. Assim, seria retirada da sociedade a prerrogativa de estabelecer os parâmetros para a defesa da propriedade. Essa, então, passaria a ser tarefa do Estado. ${ }^{20}$ Entretanto, a criação da Guarda Nacional, naquela região, não teve os fins desejados. Concorria para isso o fato de terem pessoas declaradamente de partidos políticos, ligadas aos maiores postos. Antonio Brígido dos Santos e o Capitão Antonio Ferreira Lima, homens 
elevados a postos de comando da chamada G. N., pertenciam às bases do partido liberal no Cariri Cearense e, logicamente, usavam de suas atribuições para defenderem seus interesses e os do seu partido.

De outra parte, mesmo sob a Lei que instituía a eleição para que os postos da Guarda Nacional fossem ocupados, ainda assim os vereadores da Câmara de Crato foram reticentes. Em justificativa, afirmaram que "os cidadãos mais grados refugão aseitar os postos da G. N., vindo por isso a eleição tornar-se um mal anarchico, porque impreterivelmente teremos de ver as nomiações de tais oficiais recahir em pessoas da ínfima classe da sociedade". ${ }^{21}$

A utilização do termo 'anarquia' no ofício, para aquelas autoridades, traduzia a participação popular e o receio de que tal engajamento evoluísse para uma possível 'revolução', assim como acreditavam ter acontecido anos antes na revolta de Pinto Madeira. A questão, na realidade, estava na possibilidade de ter como comandantes dos postos da G. N. pessoas que não oferecessem confiança à preservação da propriedade privada e ao poder político, resguardado pela elite senhorial.

Esse medo apenas foi sanado com a lei $\mathrm{n}^{\circ}$ 602, publicada em 19 de setembro de 1850 , quando foi abolido o processo eleitoral para a escolha dos comandantes da Guarda. Essa mudança deu espaço para que se instaurasse um caráter centralizador e político, em contrapartida da premissa descentralizadora e militar das disposições legais anteriores a esse novo código de formação da G. N. ${ }^{22}$ Segundo Maria Isaura Pereira Queirós, a formação e consolidação dessa milícia foi o caminho para a instituição do coronelismo no Brasil, sobretudo no Nordeste. "Extinta pouco depois da proclamação da República a Guarda Nacional, persistiu, no entanto, a denominação de 'coronel', outorgada espontaneamente pela população àqueles que pareciam deter entre suas mãos grandes parcelas do poder econômico e político". 23

Concordando com a publicação da lei, decorrido um mês após sua promulgação, em longo ofício enviado ao Governo Imperial, o Presidente da Província, Ignacio Francisco Silveira da Motta, considerou quatro problemas que vinha enfrentando, sobretudo em razão da falta de organização que havia para o recrutamento e a formação da Guarda Nacional. Eram eles: o ócio, a pobreza, a violência e a ignorância que via nas 'massas' pobres. Em suas palavras,

reconheço que seria muito para desejar que o Exercito Imperial não tivesse em suas fileiras, um só soldado com a pecha de ladrão ou assassino, mas também não posso deixar-se convencer-me de que no estado actual de coisas, quando as Authoridades e Tribunais Criminaes não pudem, he sem duvida a disciplina rigorosa do Exercito, 
que melhor pode fazer corrigir e tomar emenda a homens, que muitas vezes, ou talvez mesmo na generalidade, se tenhão tornado maós pela ociosidade em que vivem. (...) A Guarda Nacional acha-se em péssimo estado; na maior parte dos lugares falta-se hum Guarda Nacional; mas o que realmente são alguns indivíduos com o nome de oficiais, porque nem pelos trajos mostrão sello, he gente de camisa e ceroula, por falta de meios para se fardaram. ${ }^{24}$

Para o Presidente, a Guarda Nacional estava em péssimas condições em virtude das vicissitudes trazidas pela população que compunha o exército. Nesse sentido, era necessária uma vigilância maior, através do estabelecimento de uma disciplina mais rígida de trabalho para esses homens. Além da disciplina, essa autoridade provincial também corroborava a necessidade, como prevista na lei há um mês publicada, de que pessoas de maior nível social ocupassem os mais altos cargos; uma vez que, não apenas para esse Presidente, como para o Governo Imperial, a gente de camisa e ceroula não era de confiança.

\section{A formação de milícias privadas e as 'quadrilhas de cabras' no sertão nacional}

Na segunda metade do século XIX, é possível perceber uma política baseada na capacidade dos chefes locais de controlar a população em seu redor; ou, pelo menos, tentar controlar. Para José Murilo de Carvalho, esse seria o momento da existência de uma política de mandonismo, a governar, sobretudo, as áreas mais afastadas da Corte Imperial. ${ }^{25}$ Havia, de fato, uma percepção da precariedade do 'braço governamental' alcançar os lugares mais longínquos do interior, sobretudo as Províncias do Norte, como também havia o medo com que as populações sentindo-se desamparadas pudessem se revoltar, como outrora aconteceu.

Esse receio, contudo, parecia ser uma constante para a sociedade, não apenas em tempos de crise, e serviu de motivo para a construção de uma visão negativa - a identificação como cabra - sobre as populações pobres, sobretudo as que viviam no campo. Nas cartas escritas entre os anos de 1835 e 1837 pelo Padre José Martiniano de Alencar, nessa época Presidente do Ceará, para o Ministro e Secretário de estado dos Negócios da Fazenda, Manoel do Nascimento Castro e Silva, a referência a cabras armados já era uma preocupação presente em seus escritos. Em 17 de maio de 1835, lembrou a "cabralhada do sertão" e sua propensão a ser "insuflada pelos anarchistas". ${ }^{26}$ Já em missiva datada de 27 de maio de 1836, Alencar asseverou que "no mato tem armas, e cabras, e sempre de vez em quando dão suspeitas de quererem romper, sendo necessário conservar efetivamente fortes destacamentos na Serra Grande". ${ }^{27}$ 
Com o tempo, foram aumentando as narrativas sobre famílias ou grupos relacionados à vida 'no mato', com armas e pela prática de roubos e assassinatos. Tais manifestações tinham maior espaço quando a região passava por alguma dificuldade econômica, em grande medida relacionadas às secas; contudo, em todo o século XIX as autoridades e a elite senhorial sul cearense se ressentiram da passagem, ou mesmo pousada, desses grupos na região. Em 1849, nos ofícios enviados ao Governo imperial, havia a denúncia de que em "Crato appareceo hum movimento armado. Já não he a primeira vez que taes noticias se espalhão". ${ }^{28}$ Para minimizar o temor de uma investida contra a segurança pública, o presidente do Ceará, Fausto Augusto d'Aguiar, asseverou que as notícias de intranquilidade foram dissipadas pelo partido de oposição, desejoso de pôr fim ao seu governo.

Nada obstante, o jornal $O$ Araripe também fez referência a esses grupos, sobretudo de famílias, como os Serenos, considerados desordeiros. Nos anúncios finais de cada edição eram relatados roubos e assassinatos e estes sempre apareciam vinculados aos grupos que rodeavam a região caririense. Em alguns casos, tornavam algumas linhagens célebres pelo medo que infundiam na população. Foi assim também com os Tapiôcas e os Chios.

Em correspondência enviada ao periódico, um autor autointitulado O Governista relatou que

em 1844, apparecerão certos assombramentos dentro desta cidade, que o povo tomou por mao agouro: não tardou muito em aparecerem certos furtos e mesmo roubos em algumas casas; logo de pois (oh! Miséria das misérias) cobriu-se a Comarca do Crato de uma chusma de Penitentes que levantando cruses em todas as estradas geraes, e particulares, e mesmo em alguns sítios; por toda a parte se ouvião as vozes dessas chusmas de ladrões, cantando terços; benditos, ladainhas e pedindo esmolas; e foi tamanho o seo arrojo, que lançou-se dentro da Matris do Crato, que pareceo querer demolir o seo sagrado templo; e tantos forão os berros de taes ladrões, que causou terror a muita gente; ate ali ia-se furtando por partidas; e também matava-se por quarentena, te que enfim; e para cúmulo de desgraças chegou o fatalíssimo anno $=1845=($ anno $)$ na verdade de dolorosas, e tristíssimas recordações para os Caririenses!!!

Aquele anno arrastou para dentro do Cariry gente de todos os sertões das províncias lemitrofes a esta Comarca: entre esta gente figurava com a mais pomposa destinção o lusidissimo regimento dos Tapiôcas; na sua vanguarda florecia um brilhante esquadrão de - Serenos -; sua retaguarda era coberta pelo manco batalhão do - Chio - que tudo queria em silencio para melhor aproveitar suas deligencias. Estes três corpos aquartelando-se em huma parte desta cidade e termo prorromperão em furtos de gado, animaes, roubos de toda natureza; surras, facadas, tiros; e enfim em mortes por toda parte, ninguém contava mais com segurança da propriedade e de vida; o Cariry naquele tempo so representava um Cemiterio: o destacamento era um corpo isolado; a policia tinha feixado os olhos a todos os males passados, presentes e futuros, que sofria o infeliz povo; e o que mais era, era... ${ }^{29}$

Assustava a relação entre a religião, levada ao extremismo, como apontou o autor, e um período de dificuldades financeiras. De acordo com Hobsbawm, "historicamente, o 
banditismo e o milenarismo - as mais primitivas formas de reforma e de revolução caminham de mãos dadas. E quando sobrevêm os grandes momentos apocalípticos, os grupos de bandidos, aumentados pela fase de tribulação e expectativa, podem insensivelmente transformar-se em outra coisa". ${ }^{30}$

É fato que no Cariri Cearense, e mesmo no Nordeste brasileiro, as consecutivas secas ajudaram a dar o tom teleológico para muitos que viveram nessas regiões ao longo do século XIX e fizeram perdurar a ideia de que as dificuldades, sobretudo climáticas, trariam mais bandidos fanáticos. No entanto, não era apenas o medo do fanatismo. Na época da grande seca de 1877, o Presidente do Ceará, Estelita Pessoa, considerou serem "as classes indigentes as mais numerosas nos sertões dessa Província, revoltando-se injustamente contra a abundância dos meios de que dispõem os abastados, e intentam vingar a desigualdade pela força e pelo crime". 31

Ao cabo, a insegurança na preservação da propriedade privada era o que assustava permanentemente as autoridades, independente de crises climáticas. Em 10 de julho de 1849, Tristão de Alencar Araripe, então Presidente da Província, relatou ao Governo Imperial suas suspeitas acerca dos bandos armados.

\footnotetext{
Não é só a vida do cidadão que acometem com esse furor e desenvoltura: a propriedade tem já atrahido a ambição dos máos, que vêem tão geral transtorno nas leis da sociedade. No termo do Crato não contentes já com os roubos em pequena escala, estabeleceo-se huma companhia de ladrões com a denominação de serenos, a qual tem por fim especial furtar cavalos para vender e repartir entre os sócios os lucros adquiridos; e tal he o escândalo com que procedem, tal a publicidade e desenvoltura, com que se portão os sócios, sem que a autoridade os procure conter, que faz acreditar com razão serem os principais chefes da companhia as autoridades policiais do lugar. ${ }^{32}$
}

Tristão de Alencar Araripe, assim como outros presidentes antes e depois dele, tinha consciência de que a questão social não se tratava apenas entre grupos extremos, uma elite senhorial e as populações pobres e desassistidas; mas os embates políticos, vividos ao longo da formação da nação brasileira, terminaram por criar divisões dentro da elite senhorial. Da mesma forma indicou João Brígido, em acusação de parcialidade política entre o delegado de polícia do Crato e alguns senhores daquela cidade, que apontou quanto ao primeiro: "nunca se vio proteção mais escandalosa; esse homem continua a ser o mesmo protetor dos Domingos, e dos Quixabas e dos cabras Raimundos". 33

Ao poucos, foi elaborada a ideia de que a proteção da propriedade deveria ser empreendida pelos próprios senhores. A justiça, assim, deveria ser estabelecida em caráter 
particular. Ainda em 02 de junho de 1887, o jornal Vanguarda publicou a reclamação de que em Missão Velha,

um grupo de criminosos, entre os quaes os famigerados Lopes, foi ao sitio Barreira do cidadão Manoel Antonio de Ferreira Arruda, e ahi, a força do bacamarte, fez matolotagem de diversas vaccas paridas e algumas rezes do campo e furtou diversos animais. Decididamente este termo volta aos tempos do Viriatos e Calangros. O cidadão não encontra garantia senão na própria força. A polícia não chega para nós. ${ }^{34}$

Com a ideia de que o cidadão não encontra garantia senão na própria força, o redator do periódico apontou para uma pretensa divisão da sociedade entre bons e maus indivíduos, quanto para os interesses políticos por trás dos atos policiais. Sua justificativa estava permeada pela noção adquirida em todo o século XIX de que o braço governamental não atingia as regiões mais distantes do litoral e, portanto, estava facultada a formação de milícias particulares.

O interesse, no entanto, se restringia necessariamente à proteção da propriedade não apenas dos grupos armados, mas também dos senhores inimigos. Para isso, entendeu-se como imperativo, a formação de bandos armados para a proteção privada, e esses 'exércitos' foram geralmente forjados no próprio contingente de trabalhadores de que os senhores dispunham. A fim de agregar esses homens em sua causa, os senhores passaram a constituir relações com caráter de troca com seus trabalhadores. De acordo com Emilia Viotti da Costa, "os trabalhadores livres constituíam a clientela do senhor. Eram capangas, cabos eleitorais e, quando se fazia necessário, eleitores. Secundavam o senhor nas suas lutas políticas. Formavam sua milícia particular".35

As relações estabelecidas entre senhores e seus trabalhadores eram, conforme apontou Viotti da Costa, permeadas por traços de uma cultura de vínculo desigual entre possuídos e despossuídos. Tais laços nem sempre se mostravam tão evidentes - como no relato de Estelita Pessoa, citado anteriormente, para a época da grande seca de 1877 , quando a crise evidenciava a natureza desigual das relações -, ${ }^{36}$ mas a partir de uma imposição mascarada por uma relação de troca entre trabalho, moradia e proteção. Os dois lados tinham a aparente ideia de que podiam barganhar algum 'conforto' nessa relação, muito embora os senhores controlassem quase que totalmente os seus rumos.

Dessa maneira, foi estabelecida uma relação de troca em que os 'homens do senhor' figuravam muitas das vezes como os seus 'capangas', ou mesmo como seu exército de 
proteção. Por essa razão, esses homens passaram a receber o epíteto de 'cabras', 'cangaceiros' e mesmo 'assassinos de profissão', como foi com Gonçalo de Castro.

Gonçalo de Castro, cabra assassino de profissão, matador: há 19 annos que ouço falar dele sempre debaixo da especial proteção de Manoel José de Sousa e sua quadrilha, morador no Salgadinho, sua antiga guarida nas imediações deste termo e Província com o de Piancó e Parahiba, lugares apropriados para esconderijos de um réprobo como Gonçalo de Castro e outrem que ahi buscar o refugio furtando-se aos bem merecidos castigos. ${ }^{37}$

O relato descrevendo Gonçalo de Castro reunia as qualificações que eram impostas aos 'homens dos senhores' do Cariri Cearense, sobretudo a vida criminosa e a relação de proteção com um senhor. Contudo, ia além. Apontava para um estilo de vida- nas vestimentas, camisa e ceroula, mas também na frequente criminalização, visto pelo Presidente da Província, João Oliveira Sousa, como sendo compartilhado no sertão. ${ }^{38}$ A narração levando em conta a fácil mobilidade para deslocar-se entre o Ceará e as Províncias limítrofes e a 'profissão matador', aliada a construção que existia sobre o cabra indicava uma percepção que considerava o desenvolvimento do que viria a ser chamado de cangaço na região.

Joaquim Alves, ao escrever sobre a gênese da sociedade rural no Cariri Cearense, considerou que essa formação miliciana terminou por proporcionar o aparecimento do cangaceirismo nessa região. E o fez apresentando sua visão em artigo intitulado "como se processou a formação dos elementos sociais responsáveis pelo cangaço no Cariri”.Para esse autor, a interdependência em que viviam os senhores rurais, relacionados sobretudo com os sertões dos estados vizinhos, trouxe para o Cariri "as lutas domesticas que se desenvolviam nas suas áreas de criar, determinando a invasão de homens d'armas de Pernambuco e Paraíba no Cariri e destes para aqueles Estados". Assim, segundo Alves, "os senhores, faltos de recursos, deixaram aos seus homens, vindos da plebe rural, a realização dos seus negócios armados". ${ }^{39}$ Situando, dessa maneira, a formação do cangaceirismo como um processo lógico na formação social do Cariri Cearense. Ao tratar em termos de plebe rural, o autor necessariamente fazia referência ao componente étnico, nas suas palavras, referindo-se à constituição de bandos armados por parte dos senhores. Interessante perceber como seu entendimento estava baseado na visão do século XIX, sobretudo em sua segunda metade, em relação às populações pobres, entendidas necessariamente como violentas.

Outro intelectual cearense, Gustavo Barroso, foi mais ousado e definiu os cangaceiros, em sua obra Terra de Sol (natureza e costumes do Norte), de 1912, como 'tipos anormais', ao lado dos que intitulou como curandeiros. Provavelmente tentando desenhar os 'tipos' 
existentes no Ceará, Barroso procurou delimitar a determinados homens as características que considerou 'fora do normal'. Entretanto, em seu próprio relato o autor se contradisse ao afirmar que esses tipos pareciam bastante corriqueiros, sobretudos para o sul do Ceará. Para o autor, "o cangaceiro do Norte é selvático e feroz, sofrendo de um descalabro nervoso produto da ancestralidade e do cruzamento étnico". ${ }^{40}$ Aliando, dessa maneira, a ideia da "raça negra' a desvios no comportamento social dos indivíduos que pertenciam a essa categorização.

Assim como Alves, Barroso considerou a mistura étnica o elemento de degenerescência que contribuía para a formação dos cangaceiros do sertão caririense. Essa região era, para o autor, o espaço escolhido para o desenvolvimento do cangaço. Ainda em suas palavras,

toda a zona meridional do Ceará, enterrando-se como uma cunha entre os Estados do Piauí, Paraíba, Rio Grande e Pernambuco, a zona do Cariri, elevando-se do plano raso de sertão e estendendo-se vastamente num chapadão batido, plano, fértil, sem flagelo de seca, de vegetação luxuriante e pastagens magníficas, calçado aqui e ali de folhelos endurecidos, de grandes lajes calcárias, pontilhado de cidades ricas com vida própria, - entrepostos de comércio com mais longínquos sertões, sem a menor via de comunicação e o menor policiamento, com uma herança histórica de velhas tradições revolucionárias, de pronunciamentos e banditismo, guardada nos usos sociais, é a zona do cangaço, o quartel-general, o ninho e o refúgio dos cangaceiros. Lá campeia o crime à solta, sem peias e sem repressões; lá se albergam os foragidos do sertão inteiro nos bandos numerosos dos filhos do crime, que os chefes políticos municiam e sustentam para as suas lutas intestinas. ${ }^{41}$

A visão de Barroso estava alicerçada na construção feita no Cariri Cearense, mas também para os cariris das Províncias que lhe faziam fronteira. "Não se limita a zona do cangaço à grande chapada do Cariri, do Araripe. Inflete para o Rio Grande até S. Miguel e Pau dos Ferros; alonga-se pela Paraíba até Sousa, Cajazeiras, Piancó e Pombal; alastra-se por Pernambuco, por Alagoas e Sergipe; e, marginando o S. Francisco e o Vaza-Barris, cerceia o norte da Bahia". 42

No século XIX, escrevendo sobre essa região, em ofício a ser enviado para a Corte imperial no ano de 1877, o Presidente Caetano Estelita Cavalcante Pessoa ressaltou ser "sem duvida para lamentar que aquelle lado d'esta Província seja de vez em quando visitado por celebres bandos de assassinos de Pernambuco, Parahiba e Rio Grande do Norte e que athe hoje não se tenha conseguido livrar aqueles povos de tão terríveis vizinhos" ${ }^{43}$

Evidentemente, o Presidente do Ceará tencionava relegar às outras Províncias o ônus da prisão dos que chamavam de criminosos e também da ideia que se fazia corrente de que essa região era conhecida como afeita ao resguardo de criminosos e fugitivos da polícia. 
Entretanto, havia um consenso de que era escolhida pelos que as autoridades chamavam de 'cangaceiros'. A distância da capital e do alcance do governo certamente era um atrativo para os homens que tivessem contas a acertar com a polícia ou mesmo ao Estado. Porém, era provavelmente a facilidade de ir e vir entre as províncias o que mais impulsionava os homens livres pobres a permanecerem na chamada região do Cariri. Ao cabo, os limites geográficos, para o trânsito dos homens, não significavam mudanças cabais. Por essa razão, iam e vinham com bastante tranquilidade. Essa definição, como visto nos relatos de Alves e Barroso, foi bastante propalada no século XX. Todavia, não apenas nos escritos dos intelectuais, mas na vida cotidiana, para homens que estavam ligados a um senhor além do contrato de trabalho e que se envolviam em algum tipo de crime, o epíteto cangaceiro era utilizado com frequência e, geralmente, aliado ao de cabra.

No processo realizado por ocasião de um suposto estupro que Ricardo Alves da Silva teria cometido contra a menor Nercília Victal, essa concepção ficou evidente. Ao ser interrogada sobre o réu, a testemunha de acusação, o pai da menor, alegou que "que conhece Ricardo Alves da Silva como um individuo desordeiro e perverso e metido a [DANIFICADO] foi cabra cangaceiro do [DANIFICADo] José Terto de Joaseiro". ${ }^{44}$

A acusação de que Ricardo Alves da Silva era cabra cangaceiro, terminava por desenhar o perfil de criminoso, como fora da lei, feito pelo pai da vítima e, em última instância, pela própria sociedade. O primeiro depoente do júri, José Ribeiro de Aguiar, assim como o pai da menina e as demais testemunhas do processo, ressaltou "que os costumes do acusado Ricardo Alves, são péssimos, constando que o mesmo é dado a prática de crime contra a honra bem como é arruaceiro, já tendo feito parte do grupo de malfeitores chefiado por José Terto". ${ }^{45}$ Era, em resumo, o indivíduo perturbador da pretensa ordem da sociedade, por essa razão, em denúncia contra ele, os termos cabra e cangaceiro foram utilizados para evidenciar o nível de contravenção desse indivíduo.

Em A derradeira gesta- Lampião e Nazarenos guerreando no sertão, Luitgarde Barros desconstruiu a ideia de que o cangaço tenha surgido apenas em fins do século XIX, já no período republicano. Para a autora, não foi o "afrouxamento dos controles sociais da sociedade patriarcal", era preciso considerar "que o uso da violência por elementos dos baixos estratos sociais, no banditismo, já se dava desde a terceira década do século XIX" ${ }^{46}$

Em carta enviada para publicação n'O Araripe, é possível perceber como o termo cangaceiro e, mais ainda, sua relação com o termo cabra já era de uso na sociedade. 
Nunca fui cangaceiro, he verdade porem que quando o senr Conceiçam andava com sua intriga com o finado Santos não so lhe dei armas de fogo de minha casa, como tomei prestadas e lha mandei levar, assim como mo prestei com minha pessoa a defende-lo; então o senr sultão custumava dizer-me = fique certo que se lhe tirarem a existência eu choro em cima do seo sangue, e o vingo. = Mas he que S. S. tem Deos nos lábios e o diabo no coração: meos filhos he que ficarão chorando a minha falta. Fora disto venha a minha casa e veja se tenho cartucheira pelos tornos, enquanto S. S., sendo delegado, tem as armas do governo a seo lado, e tem cartucheiras que eu vi não faz muito tempo. (...) Eu não preciso da proteção de S. S. que não tem préstimo para mim e fique certo que sua amizade eu não quero, e pode apresentar os favores que lhe devo, quer como homem, quer como particular.

F. L. Rabello Junior ${ }^{47}$

'Cangaceiro'. Tal caracterização não era aceita pelos que assim eram denominados, visto a denotação criminosa que o termo carregava. Para incriminar uma pessoa, a sociedade utilizava-se do termo cabra e o adjetivava para dar força ao seu discurso. Em contrapartida, para se livrar de uma denúncia, os acusados negavam tais epítetos relegando-os aos inimigos. Durante muito tempo, ninguém aceitava ser chamado de cabra ou cangaceiro.

O termo cabra, como ficou evidente no relato, mostrava-se, no século XIX, como a definição do lado transgressor. A acusação entendia resumir nesse termo toda a percepção social do anti comportamento. Aliado a esta noção, o autor da narrativa, Rabello Junior a justificou pela referência ao ressaltar o uso do cacete e a enfatizou com a utilização do termo fera, como sinônimo de cabra; para, assim, passar um caráter irracional ao acusado. Em contrapartida, a negativa pelo epíteto de cangaceiro que estava sendo agregado ao seu nome permite o entendimento da natureza discriminatória que a própria sociedade tinha de si.

Rabello Jr alegou nunca ter sido cangaceiro, porém admitiu o fato de auxiliar com armas e força física um senhor em suas questões com outros senhores. Também afirmou não ter medo dos inimigos e ser resguardados pelos amigos. Em sua visão, seus atos eram executados com justiça. Entretanto, a leitura feita se resumia ao lado político de cada senhor.

No Cariri Cearense, os relatos oficiais e os jornais apontavam que os senhores primavam por manter uma guarda armada que lhe servisse de proteção em caso de alguma investida de outro senhor inimigo; este, sim, com seus 'cabras cangaceiros'. No ofício enviado ao governo provincial, em 30 de julho de 1877, o presidente da Câmara, Antonio Luiz Alves Pequeno, pediu proteção contra os "homens desordeiros e seus patronos", deixando ironicamente clara uma divisão da sociedade entre homens bons e ruins. ${ }^{48}$

Nada obstante, em 1873, o mesmo vereador, o Cel. Antonio Luiz Alves Pequeno, já tinha sido acusado de "ter em sua casa própria, grande número de homens armados, a fim de fazer cumprir a viva força". No mesmo ano de 1877, ainda foi denunciado por ter "hontem a noite por dois cabras armados mandado a casa do digno Juiz de Direito da Comarca Doutor 
João Baptista de Siqueira Cavalcante". Conforme o relato, deviam entregar-lhe uma carta “concebida em termos mais insultuosos, e não encontrando-o em caza penetrarão no recinto desta e sob o pânico e terror que incutirão na excelentíssima senhora do senhor juiz obrigarãona que recebesse a carta". 49

As brigas políticas terminavam por envolver a população pobre, em especial a ampla maioria que estava ligada, por ajuste de trabalho, proteção e/ou moradia, a um senhor. Para realizar seus 'mandos' os senhores utilizavam-se dos 'seus' homens. Por, geralmente, realizarem ordens que transgrediam a lei, esses homens eram chamados de cabras.

A relação entendida como natural entre classes pobres e classes perigosas foi estudada por Sidney Chalhoub em Cidade Febril: cortiços e epidemias na Corte imperial. Para este autor, o entendimento acerca de quem eram as classes perigosas foi constituído entre autoridades e membros da elite senhorial brasileira, mais especificamente em fins dos oitocentos. Essa percepção estava relacionada à urgência, devido o questionamento do sistema escravista e a resistência de livres pobres ao trabalho agrícola, da manutenção da ordem e controle da população, sobretudo a egressa do cativeiro.

Questões como cidadania, trabalhador ideal, alcance do Estado e da polícia sobre a população, de acordo com Chalhoub, estavam permeadas pelo medo em torno das populações pobres por associarem as classes pobres à noção de classes perigosas, criando, assim uma imagem de perigo e violência principalmente sobre a população de cor que estava em processo de liberdade. Tal associação "fez com que, desde o início, os negros se tornassem os suspeitos preferenciais" e fossem considerados os representantes dessas "classes perigosas". 50

Por outro lado, o estado de briga entre os senhores era uma constante na realidade do Cariri Cearense. Impasses políticos, financeiros ou sociais, entre outros motivos, marcavam as disputas vividas diariamente e impunham a necessidade de que cada senhor mantivesse um bando armado para a sua proteção. Esse procedimento, contudo, não era novo e nem restrito ao sul cearense. Ana Paula Pereira Costa, em pesquisa sobre Minas Gerais do século XVIII, apontou "o ato de armar escravos como mecanismo comum e essencial para demonstração de poder; para o sucesso de empreitadas em que auxiliavam a Coroa portuguesa e autoridades metropolitanas, notadamente governadores, na manutenção da ordem pública e para o alcance de mercês régias que afirmariam seu status". Ainda considerou que essas ações significavam, em última instância, "uma extensão dos serviços que os escravos deviam prestar a seus donos". 51 
A formação de bandos de homens armados também parecia ser consenso por parte dos senhores da região do Cariri. O vigário Galdino deixou clara essa consciência quando mandou o recado a ser dito para o Barros que ele não o temia nem a seos cabras. O jornal $O$ Araripe, em suas matérias, também ressaltava a formação de uma 'guarda' como um costume arraigado naquela sociedade. Em 09 de agosto de 1856, publicou que

há poucos dias indo passar por essa villa [de Jardim] o sr. João Quesado e José Quesado, ambos acompanhados d'huma porção de homens, vulgo cabras, todos armados, huns de armas de fusil, outros de fouces, dis-se, para uma fazenda de nome Mameluco, (e segundo parece-me) pertence a hum tal de Antonio Monteiro para (disem huns) derribarem à força huma porção de matto, e outros para atacarem o tal Monteiro. $^{52}$

Tomando o cuidado, em alguns momentos, de ressaltar ser relato de terceiros, o redator do periódico e autor da nota optou por relacionar os homens dos Quesados ao termo cabra, insinuando ser a maneira que eram popularmente tratados. Contudo, ao incriminar os irmãos, acabava por apontar o controle que os mesmos exerciam sobre os seus homens. Posto que mantinham um 'exército' armado a seu favor.

No Cariri Cearense, desde a primeira metade do século XIX, essa foi a maneira mais utilizada para se tentar controlar os cabras. Tê-los em seu domínio, como milícia de proteção e também como seus trabalhadores - sendo agregados ou moradores -, podia ser mais vantajoso aos senhores. Em ofício ao governo do Império, o Presidente do Ceará Joaquim da Costa Araújo, apontou que "a disposição desses homens a força he hum perigo para muita gente". Por isso, era necessário que as “pessoas grandes" pudessem controlá-las. ${ }^{53}$

\section{Conclusão}

O recrutamento para a Guarda Nacional foi ponto de conturbação no processo de formação do Estado brasileiro no Oitocentos, pois estavam em discussão e em conflito projetos políticos divergentes relacionados à organização de uma milícia oficial e o alcance à propriedade privada. Como visto nas seções anteriores, a percepção sobre as dinâmicas sociais locais, bem como as relações de aliança ou conflito entre senhores e seus moradores e agregados, bem como senhores e governos provincial e imperial, contribuiu para entender o jogo em favor da propriedade privada no Brasil de meados do oitocentos. Além disso, foi possível compreender as motivações e expectativas dos camponeses ao se envolverem nos 
chamados grupos armados, que nos casos aqui analisados estavam relacionadas à defesa dos territórios e à administração desses espaços da forma que melhor conviesse aos seus interesses. Assim, articulando as discussões em torno do processo de recrutamento aos aspectos locais referentes ao alcance do braço governamental sobre senhores e populações pobres, fica evidente que a questão da segurança pública, além de aliada aos interesses da propriedade privada, foi uma discussão feita de 'alto à baixo' na constituição do Estado nacional no século XIX, embora muitas vezes marcada pelo movimento dos que se negavam a se sujeitar aos senhores do Cariri Cearense.

\section{Notas}

${ }^{1}$ Durante a primeira metade do século XIX foi gestada uma definição para os homens pobres do Cariri Cearense, sobretudo os que moravam em sítios e pés-de-serra, mais afastados, portanto, do espaço entendido como civilizado: o cabra. Esse epíteto foi dado aos homens que lutaram na Guerra do Pinto Madeira deflagrada após abdicação de Pedro I ao trono brasileiro e o estabelecimento do período regencial. Como se voltaram contra a ordem política estabelecida e a favor do primeiro Imperador, foi assimilada, por parte do governo provincial, apoiado pela Corte Imperial, uma identificação negativa de selvagens e fanáticos, inimigos da liberdade e da ordem pública. Assim, ao cabo da década de 1830, havia no Cariri Cearense a ideia de uma população que precisava ser vigiada continuamente e, mais do que isso, moldada aos interesses sociais.

${ }^{2}$ Fundação Biblioteca Nacional, Vanguarda - 1887 a 1888 - PR_SOR_00543_765724, 26 de maio de 1887, n ${ }^{\circ}$ 3, p. 03, col. 02 e p. 04, col. 01[grifo do autor e correção da autora].

${ }^{3}$ É válido ressaltar que Milagres, vila do Cariri Cearense, sustentou, até 1886, um total de 298 escravos após a declaração abolicionista empreendida pela Sociedade Cearense Libertadora, em 1884. Contudo, quando da publicação do periódico, em 26 de maio de 1887, já não havia mais registro de cativos na região.

${ }^{4}$ BALABAN, Marcelo. "Voluntários Involuntários": o recrutamento para a guerra do Paraguai nas imagens da imprensa ilustrada brasileira do século XIX. In: Mundos do Trabalho. v. 1, n. 2 (2009), pp. 221 - 256, p. 225.

${ }^{5}$ Idem ibdem.

${ }^{6}$ ARAÚJO, Johny. Bravos do Piauí! orgulhai-vos. Sois dos mais bravos batalhões do Império: a propaganda nos jornais piauienses e a mobilização para a guerra do Paraguai, 18865 - 1866. Tese de Doutorado, UFF - Instituto de Ciências Humanas e Filosofia, Departamento de História, 2009, p. 154.

${ }^{7}$ O Araripe, 09 de janeiro de $1858, \mathrm{n}^{\circ} 125$, p. 03, col. 01.

${ }^{8}$ BALABAN. Op. Cit., p. 227.

${ }^{9}$ QUEIRÓS, Maria Izaura Pereira. O coronelismo numa interpretação sociológica. In: História geral da civilização brasileira. Tomo III - O Brasil republicano. 2. ed. São Paulo: Difel, 1977. pp. 155-156.

${ }^{10}$ ALMEIDA, José Adilson de. Uniformes da Guarda Nacional: 1831-1852 a indumentária na organização e funcionamento de uma associação armada. Departamento de história, faculdade de filosofia, letras e ciências humanas da USP. Dissertação, 1999, p. 151.

${ }^{11}$ CASTRO, Jeanne Berrance de. A Milícia Cidadã: a Guarda Nacional de 1831 a 1850. São Paulo: Companhia Editora Nacional; Brasília: INL, 1977, p. 181.

12 DOLHNIKOFF, Miriam. O Pacto Imperial: origens do federalismo no Brasil do século XIX. São Paulo: Globo, 2005, p. 92.

${ }^{13}$ CÂMARA MUNICIPAL DO CRATO. Ofício da Câmara Municipal do Crato ao Presidente da Província do Ceará, Brigadeiro José Joaquim Coelho, em 18 de outubro de 1841, caixa 34, APEC, folha 1.

${ }^{14}$ CÂMARA MUNICIPAL DO CRATO. Ofício da Câmara Municipal do Crato ao Presidente da Província do Ceará, Brigadeiro José Joaquim Coelho, em 18 de outubro de 1841, caixa 34, APEC, folha 2.

${ }^{15} O$ Araripe, 21 de fevereiro de $1857, \mathrm{n}^{\circ} 83$, p. 03, col. 01 e 02.

${ }^{16} \mathrm{O}$ Araripe, 20 de fevereiro de 1858, $\mathrm{n}^{\circ} 131$, p. 02, col. 02.

${ }^{17}$ CÂMARA MUNICIPAL DO CRATO. Ofício da Câmara Municipal do Crato ao Presidente da Província do Ceará, Cazimiro Jose de Morais Sarmento, em 08 de novembro de 1847, caixa 34, APEC, folhas 1 a 5. 
${ }^{18} O$ Araripe, 06 de outubro de $1855, \mathrm{n}^{\circ} 14$, p. 02 , col. 02 e p. 03, col. 01.

${ }^{19} \mathrm{O}$ Araripe, 20 de setembro de $1856, \mathrm{n}^{\circ}$ 62, p. 01, col. 02.

20 Ainda conforme Peres, "em 1831, com a abdicação, no mesmo movimento em que se completava a nacionalização do aparelho do Estado, desmobilizou-se virtualmente o segmento nacional do exército de linha, que se sublevara contra os privilégios da oficialidade ainda predominantemente portuguesa. Criou-se em seu lugar a Guarda Nacional, força miliciana sob controle dos grandes latifundiários, não paga, destinada à manutenção da ordem interna”. PERES, Wilma. A Economia Mercantil Escravista Nacional e o processo de construção do Estado no Brasil (1808-1850). In: SZMRECSÁNYI, Tamás \& LAPA, José Roberto do Amaral (orgs.). História Econômica da Independência e do Império. São Paulo: Hucitec/ Associação Brasileira de pesquisadores em História Econômica/ editora da Universidade de São Paulo/ Imprensa Oficial, 2002, p. 155.

${ }^{21}$ CÂMARA MUNICIPAL DO CRATO. Ofício da Câmara Municipal do Crato ao Presidente da Província do Ceará, Manoel Felizardo de Souza e Mello, em 12 de dezembro de 1838, caixa 34, APEC, folhas 1 e 2.

${ }^{22}$ Ver mais: CAVALCANTI, Robinson. As Origens do Coronelismo: força armada e poder local no Estado patrimonial brasileiro. Recife: Editora da UFPE, 1984. p. 84.

${ }^{23}$ QUEIRÓS. Op. Cit., 1977. p. 155-156.

${ }^{24}$ Arquivo Nacional, Ast IJJ9 176, 1850.

${ }^{25}$ Em suas palavras, mandonismo "refere-se à existência local de estruturas oligárquicas e personalizadas de poder. O mandão, o potentado, o chefe, ou mesmo o coronel como indivíduo, é aquele que, em função do controle de algum recurso estratégico, em geral a posse da terra, exerce sobre a população um domínio pessoal e arbitrário que a impede de ter livre acesso ao mercado e à sociedade política. O mandonismo não é um sistema, é uma característica da política tradicional. Existe desde o início da colonização e sobrevive ainda hoje em regiões isoladas. A tendência é que desapareça completamente à medida que os direitos civis e políticos alcancem todos os cidadãos. A história do mandonismo confunde-se com a história da formação da cidadania". CARVALHO, José Murilo de. Mandonismo, Coronelismo, Clientelismo: Uma Discussão Conceitual. In: Dados, vol. 40, no. 2, Rio de Janeiro, 1997, pp. 1 - 9, p. 2.

${ }^{26}$ ALENCAR, José M. de. Cartas do Padre José Martiniano de Alencar, Presidente do Ceará, ao Ministro e Secretário de estado dos Negócios da Fazenda, Manoel do Nascimento Castro e Silva. In: Revista do Instituto do Ceará. Fortaleza, Instituto do Ceará, 1908, p. 34 e 35.

${ }^{27}$ ALENCAR, José M. de. Cartas do Padre José Martiniano de Alencar, Presidente do Ceará, ao Ministro e Secretário de estado dos Negócios da Fazenda, Manoel do Nascimento Castro e Silva. In: Revista do Instituto do Ceará. Fortaleza, Instituto do Ceará, 1908, p. 78.

${ }^{28}$ GOVERNO DA PROVÍNCIA DO CEARÁ. Ofício do Governo da Província do Ceará ao Conselheiro Visconde de Monte Alegre, Ministro e Secretario d'Estado dos Negócios do Império, em 9 de janeiro de 1849, Arquivo Nacional, Ast IJJ9 176, 1849, folha 1.

${ }^{29}$ O Araripe, 14 de junho de 1856, $\mathrm{n}^{\circ} 48$, p. 03, col. 02.

${ }^{30}$ HOBSBAWM, Eric J. Bandidos. 4 ed. São Paulo, Paz e Terra, 2010, p. 49.

${ }^{31}$ Arquivo Nacional, Ast IJJ9 188, 1877.

${ }^{32}$ Arquivo Nacional, Ast IJJ9 176, 1849.

${ }^{33}$ O Araripe, 20 de dezembro de $1856, \mathrm{n}^{\circ} 74$, p. 03, col. 02.

${ }^{34}$ Fundação Biblioteca Nacional, Vanguarda - 1887 a 1888 - PR_SOR_00543_765724, 02 de junho de 1887, n ${ }^{\circ}$ 4, p. 02, col. 02 e p. 03, col. 01.

${ }^{35}$ COSTA, Emília Viotti da. Da senzala à colônia.4 ed. São Paulo: Fundação Editora da UNESP, 1998 , pp. 280 e 281.

${ }^{36}$ Arquivo Nacional, Ast IJJ9 188, 1877.

${ }^{37}$ Arquivo Nacional, Ast IJJ9 178, 1858.

${ }^{38}$ Ver mais em CORTEZ IRFFI, Ana Sara R. P. O Cabra do Cariri Cearense - A invenção de um conceito oitocentista. Tese de Doutorado em História Social, UFC, 2015.

39 ALVES, Joaquim. O vale do Cariri: características físicas, povoamento, população, vida econômica, desenvolvimento cultural. Fortaleza: Instituto do Ceará, 1946, p. 122 e 123 [grifo do autor].

${ }^{40}$ BARROSO, Gustavo. Terra do Sol. 2 ed. Rio de Janeiro: Editora Benjamin de Aguillar, 1987, p. 144.

${ }^{41}$ BARROSO. Op. Cit., p. 148.

${ }^{42}$ Idem, p. 149.

${ }^{43}$ Arquivo Nacional, Ast IJJ9 188, 1877.

${ }^{44}$ CEDOC - Centro de Documentação do Cariri, Processos Criminais, Caixa 7, Pasta 112, Ano 1929.

${ }^{45}$ CEDOC - Centro de Documentação do Cariri, Processos Criminais, Caixa 7, Pasta 112, Ano 1929.

${ }^{46}$ BARROS, Luitgarde Oliveira Cavalcanti. A derradeira gesta - Lampião e Nazarenos guerreando no sertão. 2 ed. Rio de Janeiro: Mauad, 2000, p. 23. 


\footnotetext{
${ }^{47}$ O Araripe, 13 de outubro de 1860, $\mathrm{n}^{\circ}$ 239, p. 03, col. 02 e p. 04, col. 01.

${ }^{48}$ CÂMARA MUNICIPAL DO CRATO. Ofício da Câmara Municipal do Crato ao Senador Pedro Leão Velozo, em 30 de julho de 1877, caixa 34, APEC, folha 2.

${ }^{49}$ CÂMARA MUNICIPAL DO CRATO. Cópia de denúncia contra Antonio Luiz Alves Pequeno recebida feita em 1877 pelo Tabelião Público Emigdio Odorico de Morais. Cópia realizada em 18 de junho de 1881, caixa 34, APEC, folha 3.

${ }^{50}$ CHALHOUB. Op. Cit., 1996, p. $21-24$.

${ }^{51}$ COSTA, Ana Paula Pereira. Potentados locais e seu braço armado: as vantagens e dificuldades advindas do armamento de escravos na conquista das Minas. In: Topoi, v. 14, n. 26, jan./jul. 2013, p. 18-32, p. 23.

${ }^{52} O$ Araripe, 09 de agosto de 1856, $\mathrm{n}^{\circ}$ 56, p. 03, col. 01.

${ }^{53}$ Arquivo Nacional, Ast IJJ9 177, 1856.
}

\section{Referências Bibliográficas}

ALMEIDA, José Adilson de. Uniformes da Guarda Nacional: 1831-1852 a indumentária na organização e funcionamento de uma associação armada. Departamento de história, faculdade de filosofia, letras e ciências humanas da USP. Dissertação, 1999.

ALVES, Joaquim. O vale do Cariri: características físicas, povoamento, população, vida econômica, desenvolvimento cultural. Fortaleza: Instituto do Ceará, 1946.

ARAÚJO, Johny. Bravos do Piauí! orgulhai-vos. Sois dos mais bravos batalhões do Império: a propaganda nos jornais piauienses e a mobilização para a guerra do Paraguai, 18865 - 1866. Tese de Doutorado, UFF - Instituto de Ciências Humanas e Filosofia, Departamento de História, 2009.

BALABAN, Marcelo. "Voluntários Involuntários": o recrutamento para a guerra do Paraguai nas imagens da imprensa ilustrada brasileira do século XIX. In: Mundos do Trabalho. v. 1, n. 2 (2009), pp. $221-256$.

BARROS, Luitgarde Oliveira Cavalcanti. A derradeira gesta - Lampião e Nazarenos guerreando no sertão. 2 ed. Rio de Janeiro: Mauad, 2000.

BARROSO, Gustavo. Terra do Sol. 2 ed. Rio de Janeiro: Editora Benjamin de Aguillar, 1987

CARVALHO, José Murilo de. Mandonismo, Coronelismo, Clientelismo: Uma Discussão Conceitual. In: Dados, vol. 40, no. 2, Rio de Janeiro, 1997.

CASTRO, Jeanne Berrance de. A Milícia Cidadã: a Guarda Nacional de 1831 a 1850 . São Paulo: Companhia Editora Nacional; Brasília: INL, 1977.

CAVALCANTI, Robinson. As Origens do Coronelismo: força armada e poder local no Estado patrimonial brasileiro. Recife: Editora da UFPE, 1984.

COSTA, Ana Paula Pereira. Potentados locais e seu braço armado: as vantagens e dificuldades advindas do armamento de escravos na conquista das Minas. In: Topoi, v. 14, n. 26, jan./jul. 2013, p. 18-32. 
COSTA, Emília Viotti da. Da senzala à colônia.4 ed. São Paulo: Fundação Editora da UNESP, 1998.

DOLHNIKOFF, Miriam. O Pacto Imperial: origens do federalismo no Brasil do século XIX. São Paulo: Globo, 2005.

HOBSBAWM, Eric J. Bandidos. 4 ed. São Paulo, Paz e Terra, 2010.

PERES, Wilma. A Economia Mercantil Escravista Nacional e o processo de construção do Estado no Brasil (1808-1850). In: SZMRECSÁNYI, Tamás \& LAPA, José Roberto do Amaral (orgs.). História Econômica da Independência e do Império. São Paulo: Hucitec/ Associação Brasileira de pesquisadores em História Econômica/ editora da Universidade de São Paulo/ Imprensa Oficial, 2002.

QUEIRÓS, Maria Izaura Pereira. O coronelismo numa interpretação sociológica. In: História geral da civilização brasileira. Tomo III - O Brasil republicano. 2. ed. São Paulo: Difel, 1977. 